a reduced model (with $\mathrm{k}$ parameters) is asymptotically distributed as a $\chi^{2}$ with $\mathrm{m}-\mathrm{k}$ degrees of freedom.

1 McConnell RB. Inflammatory bowel disease: newer views of genetic influence. In: Berk JE, ed. Developments in digestive diseases. Philadelphia: Lea and Febiger, 1980:129-37.

2 Farmer RG, Michener WM, Mortimer EA. Studies of family history among patients with inflammatory bowel disease. Clin Gastroenterol 1980;9:271-8.

3 Lashner BA, Evans AA, Kirsner JB, Hanauer SB. Prevalence and incidence of inflammatory bowel disease in family members. Gastroenterology 1986;91: 1396-400.

4 Monsén U, Broström O, Nordenvall B, Sörstad J, Hellers G. Prevalence of inflammatory bowel disease among relatives of patients with ulcerative colitis. Scand f Gastroenterol 1987;22:214-8.

5 Monsén U, Bernell O, Johansson C, Hellers G. Prevalence of inflammatory bowel disease among relatives of patients with Crohn's disease. Scand $\mathcal{f}$ Gastroenterol 1991;26:302-6.

6 Orholm M, Munkholm P, Langholz E, Nielsen OH, Sørensen TIA, Binder V. Familial occurrence of inflammatory bowel disease. N Engl f Med 1991;324: $84-8$

7 Lalouel JM, Morton NE. Complex segregation analysis with pointers. Hum Hered 1981;31:312-21.

8 Binder V, Both H, Hansen PK, Hendriksen C, Kreiner S, Torp-Pedersen K. Incidence and prevalence of ulcerative colitis and Crohn's disease in the county of Copenhagen, 1962 to 1978 . Gastroenterology 1982;83:563-8.

9 Munkholm P, Langholz E, Nielsen OH, Kreiner S, Binder V. Incidence and prevalence of Crohn's disease in the county of Copenhagen, 1962-87: a sixfold increase in incidence. Scand 7 Gastroenterol 1992;27: $609-14$
10 Langholz E, Munkholm P, Nielsen OH, Kreiner S, Binder V. Incidence and prevalence of ulcerative colitis in Copenhagen county from 1962 to 1987. Scand f Gastroenterol 1991;26:1247-56.

11 Khoury MJ, Beaty TH, Liang K-Y. Can familial aggregation of disease be explained by familial aggregation of environmental risk factors? Am I Epidemiol 1988;127:674-83

12 Monsén U, Iselius L, Johansson C, Hellers G. Evidence for a major additive gene in ulcerative colitis. Clin Genet 1989;36:411-4.

3 Monsén U. Inflammatory bowel disease. An epidemiological and genetic study [thesis]. Stockholm: Carolinska Medico Chirurgiska Institutet, 1990.

14 Küster W, Pascoe L, Purrmann J, Funk S, Majewski F. The genetics of Crohn disease: complex segregation analysis of a family study with 265 patients with Crohn disease and 5,387 relatives. Am J Med Genet 1989;32:105-8.

15 Binder V, Hendriksen C, Kreiner S. Prognosis in Crohn's disease-based on results from a regional patient group from the county of Copenhagen. Gut 1985;26:146-50.

16 Hendriksen C, Kreiner S, Binder V. Long term prognosis in ulcerative colitis-based on results from a regional patient group from the county of Copenhagen. Gut 1985;26:158-63.

17 McConnell RB, Shaw JM, Whibley EJ, McConnell TH. Inflammatory bowel disease: a review of previous genetic studies and the Liverpool family data. In: McConnell R, Rozen P, Langman M, Gilar T, eds. The genetics and epidemiology of inflammatory bowel disease. Vol 11. Frontiers of gastrointestinal research. Basle: Karger, 1986:1-1

18 Tysk C, Lindberg E, Järnerot G, Flodérus-Myrhed B. Ulcerative colitis and Crohn's disease in an unselected population of monozygotic and dizygotic twins: a study of heritability and the influence of smoking. Gut 1988;29: 990-6.

(Accepted 30 October 1992)

\title{
Initiation of hypertension in utero and its amplification throughout life
}

\author{
C M Law, M de Swiet, C Osmond, P M Fayers, DJP Barker, AM Cruddas, CHD Fall
}

Abstract

Objective-To determine whether the relation between high blood pressure and low birth weight is initiated in utero or during infancy, and whether it changes with age.

Design-A longitudinal study of children and three follow up studies of adults.

Setting-Farnborough, Preston, and Hertfordshire, England, and a national sample in Britain.

Subjects -1895 children aged 0-10 years, 3240 men and women aged 36 years, 459 men and women aged 46-54 years, and 1231 men and women aged 59-71 years. The birth weight of all subjects had been recorded.

Main outcome measure-Systolic blood pressure.

Results-At all ages beyond infancy people who had lower birth weight had higher systolic blood pressure. Systolic blood pressure was not related to growth during infancy independently of birth weight. The relation between systolic pressure and birth weight became larger with increasing age so that, after current body mass was allowed for, systolic pressure at ages 64-71 years decreased by $5.2 \mathrm{~mm} \mathrm{Hg}$ $(95 \%$ confidence interval 1.8 to 8.6$)$ for every $k g$ increase in birth weight.

Conclusions-Essential hypertension is initiated in fetal life. A raised blood pressure is then amplified from infancy to old age, perhaps by a positive feedback mechanism.

\section{Introduction}

Folkow suggested that there are two components in the aetiology of essential hypertension: an initiating process raises the blood pressure, and an amplifying process progressively magnifies the difference throughout life. ${ }^{1}$ If this is true, the initiating abnormality could be difficult to detect because it would have a small effect on blood pressure in the early years of the disease. There is little evidence on whether amplification occurs in essential hypertension, though the rise in blood pressure with increasing age is consistent with this. It is clear that amplification occurs in secondary hypertension. In patients with phaeochromocytoma, Conn's syndrome, or renal artery stenosis, hyperten- sion can persist even after the primary cause, the tumour or stenosis, has been removed. ${ }^{23}$

Recent work has shown that raised blood pressure in adults is associated with reduced growth in early life..$^{45}$ Mean systolic and diastolic pressures of men and women in middle and late life fall progressively from those with the lowest birth weights to those with the highest. Blood pressure is also higher in those whose birth weights were low in relation to that expected from their placental weights. ${ }^{4}$ Children show similar relations. ${ }^{6}$ These findings could indicate that high adult blood pressure is initiated in utero. Alternatively, healthy infants of low birth weight may have accelerated growth, so called catch up growth, during the first six months of life. ${ }^{78}$ If this accelerated early growth were accompanied by an accelerated rise in blood pressure, then the values would be set on a higher than expected plane when tracking of blood pressure becomes established after 6 months of age. ${ }^{9}{ }^{10}$

We examined the timing of initiation of high blood pressure and the occurrence of amplification by bringing together data from four studies of children and adults in Britain.

\section{Methods}

We used data from the following studies. In two of them (Farnborough and Hertfordshire) weight at 1 year of age was recorded in addition to birth weight.

\section{CHILDREN}

Farnborough-The Brompton study of blood pressure was based on 1895 consecutive term ( $\geqslant 38$ completed weeks of pregnancy) births at Farnborough Hospital, Kent, from 1975 to 1977 . The infants were followed up at 4 days, 6 weeks, 6 months, 1 year, and yearly thereafter to the age of 10 years; at each age systolic pressure and weight were measured by a standardised procedure. A $4 \mathrm{~cm}$ cuff was used at ages up to 6 months, an $8 \mathrm{~cm}$ cuff from 6 months to 8 years, and a $12 \mathrm{~cm}$ cuff on some children aged 5-8 years and all children from 8-10 years. Details of the methods and follow up rates have been published. ${ }^{9}$ We excluded two children born at more than 42 completed weeks of pregnancy. 
1946 cohort-The Medical Research Council's national survey of health and development comprises 5362 men and women born in Britain in one week in March 1946. Birth weight was recorded in pounds ( 1 pound $=0.45 \mathrm{~kg}$ ). At the age of 36 years, $3240 \mathrm{had}$ their blood pressure measured by a standardised procedure. Details of the methods have been published; the results presented are derived from the published reports. ${ }^{11}$

Preston-In Sharoe Green Hospital, Preston, detailed records of pregnancy and delivery were preserved. Birth weight was measured in pounds. A total of 459 men and women who were born in this hospital and still lived in Lancashire had their blood pressure measured by a standardised procedure at a mean age of 50 (range 46-54) years. Details of the methods have been published.

Hertfordshire-In the county of Hertfordshire from 1911 onwards each birth was notified by the attending midwife, who recorded birth weight. A health visitor saw the child at home periodically through infancy and recorded weight at 1 year. Weights were measured in pounds. A total of 844 men

TABLE I-Systolic pressure and birth weight

\begin{tabular}{|c|c|c|}
\hline Age & $\begin{array}{l}\text { Mean (SD) unadjusted } \\
\text { systolic pressure } \\
(\mathrm{mm} \mathrm{Hg})\end{array}$ & $\begin{array}{l}\text { Mean (SE) difference in } \\
\text { systolic pressure per kg } \\
\text { increase in birth weight }\end{array}$ \\
\hline \multicolumn{3}{|c|}{ Farnborough } \\
\hline 4 Days $(n=1739)$ & $72(9)$ & $-1 \cdot 0(1 \cdot 4)$ \\
\hline 6 Weeks $(n=1628)$ & $93(11)$ & $-0.8(0.8)$ \\
\hline 6 Months $(n=863)$ & $93(14)$ & $-0.6(1 \cdot 0)$ \\
\hline 1 Year $(n=1344)$ & $94(11)$ & $0.4(0.7)$ \\
\hline 2 Years $(n=1313)$ & $96(11)$ & $-0.3(0.7)$ \\
\hline 3 Years $(n=1215)$ & $97(10)$ & $-1.4(0 \cdot 7)$ \\
\hline 4 Years $(n=1147)$ & $97(9)$ & $-2.5(0 \cdot 6)$ \\
\hline 5 Years $(n=994)$ & $96(10)$ & $-1 \cdot 1(0 \cdot 7)$ \\
\hline 6 Years $(n=1070)$ & $93(9)$ & $-1.9(0.6)$ \\
\hline 7 Years $(n=1066)$ & $91(9)$ & $-1 \cdot 1(0 \cdot 6)$ \\
\hline 8 Years $(n=1093)$ & $91(9)$ & $-1.6(0.5)$ \\
\hline 9 Years $(n=961)$ & $92(9)$ & $-0.7(0.6)$ \\
\hline 10 Years $(n=445)$ & $94(9)$ & $-1.3(0.9)$ \\
\hline \multicolumn{3}{|c|}{1946 National cohon } \\
\hline \multicolumn{3}{|l|}{36 years } \\
\hline $\operatorname{Men}(n=1630)$ & $123(15)$ & $-2 \cdot 3$ \\
\hline Women $(n=1610)$ & $118(15)$ & $-2 \cdot 0$ \\
\hline \multicolumn{3}{|c|}{ Preston } \\
\hline \multicolumn{3}{|l|}{$46-50.9$ Years } \\
\hline $\operatorname{Men}(n=123)$ & $154(20)$ & $-2 \cdot 8(3 \cdot 3)$ \\
\hline Women $(n=116)$ & $143(22)$ & $-2 \cdot 7(4 \cdot 0)$ \\
\hline \multicolumn{3}{|l|}{ 51-54 Years } \\
\hline $\operatorname{Men}(n=117)$ & $154(19)$ & $-3 \cdot 4(2 \cdot 9)$ \\
\hline Women $(n=103)$ & $149(26)$ & $-3 \cdot 4(5 \cdot 2)$ \\
\hline \multicolumn{3}{|c|}{ Hertfordshire } \\
\hline \multicolumn{3}{|l|}{$59-63.9$ Years } \\
\hline $\operatorname{Men}(n=426)$ & $162(23)$ & $-3 \cdot 0(2 \cdot 0)$ \\
\hline Women $(n=203)$ & $159(23)$ & $-2 \cdot 7(3 \cdot 1)$ \\
\hline \multicolumn{3}{|l|}{ 64-71 Years } \\
\hline $\operatorname{Men}(n=418)$ & $166(24)$ & $-4 \cdot 9(2 \cdot 0)$ \\
\hline Women $(n=184)$ & $161(26)$ & $-5 \cdot 5(3 \cdot 4)$ \\
\hline
\end{tabular}

TABLE II-Correlation between birth weight, weight at 1 year, and current measures

\begin{tabular}{|c|c|c|}
\hline & Birth weight & Weight at one year \\
\hline \multicolumn{3}{|l|}{ Children aged 4 years (Farnborough) } \\
\hline Weight at 1 year & 0.39 & \\
\hline $\begin{array}{l}\text { Weight at } 4 \text { years } \\
\text { Adults aged } 64 \text { years (Hertfordshire) }\end{array}$ & $0 \cdot 34$ & 0.59 \\
\hline Weight at 1 year & 0.41 & \\
\hline Body mass index at 64 years & $0 \cdot 12$ & $0 \cdot 12$ \\
\hline
\end{tabular}

TABLE III-Mean systolic pressure $(\mathrm{mm} \mathrm{Hg})$ at age 4 years according to birth weight and weight at 4 years

\begin{tabular}{lccccc}
\hline & \multicolumn{5}{c}{ Weight at 4 years $(\mathrm{kg})$} \\
\cline { 2 - 5 } Birth weight (grams) & \multicolumn{1}{c}{ To $15 \cdot 9(\mathrm{n}=256)$} & To $16 \cdot 8(\mathrm{n}=241)$ & To $18 \cdot 0(\mathrm{n}=199)$ & $>18 \cdot 0(\mathrm{n}=295)$ & Total $(\mathrm{n}=991)$ \\
\hline To 3060 & $95(\mathrm{n}=98)$ & $97(\mathrm{n}=60)$ & $102(\mathrm{n}=43)$ & $100(\mathrm{n}=53)$ & $98(\mathrm{n}=254)$ \\
To 3360 & $97(\mathrm{n}=74)$ & $98(\mathrm{n}=62)$ & $97(\mathrm{n}=60)$ & $103(\mathrm{n}=48)$ & $99(\mathrm{n}=244)$ \\
To 3650 & $95(\mathrm{n}=53)$ & $96(\mathrm{n}=72)$ & $98(\mathrm{n}=57)$ & $99(\mathrm{n}=68)$ & $97(\mathrm{n}=250)$ \\
$>3650$ & $92(\mathrm{n}=31)$ & $95(\mathrm{n}=47)$ & $94(\mathrm{n}=39)$ & $100(\mathrm{n}=126)$ & $97(\mathrm{n}=243)$ \\
Total & 95 & 97 & 98 & 100 & $98^{\star}$ \\
\hline
\end{tabular}

${ }^{\star}$ Overall standard deviation $=10 \mathrm{~mm} \mathrm{Hg}$ to systolic blood pressure at age 4 years, taking account of current weight

\begin{tabular}{lccc}
\hline & $\begin{array}{c}\text { Mean difference in } \\
\text { systolic pressure } \\
\text { (mm Hg) per kg } \\
\text { increase in weight }\end{array}$ & $\begin{array}{c}95 \% \\
\text { Confidence } \\
\text { interval }\end{array}$ & p Value \\
\hline Weight $(\mathrm{kg})$ & -2.8 & -4.1 to -1.4 & $<0.0001$ \\
\hline At birth & 0.1 & -0.5 to 0.8 & 0.7 \\
At 1 year & 1.5 & 1.1 to 1.8 & $<0.0001$ \\
At 4 years & & & \\
\hline
\end{tabular}

Standard error of residuals $=8.9 \mathrm{~mm} \mathrm{Hg}$.

who were born in east Hertfordshire during 1920-30 and who still lived there had their blood pressure measured by a standardised procedure at a mean age of 64 (59-70) years. Details of the methods have been published. ${ }^{12}$ The blood pressure of 387 women born in the same area during 1923-30 was measured similarly at a mean age of $64(60-71)$ years. The body mass of all except six subjects was recorded.

\section{STATISTICAL METHODS}

Table I shows the mean unadjusted systolic pressures. Systolic pressures were adjusted by linear regression to allow for the effects of influential variables. In Farnborough systolic pressure was adjusted for cuff size. Mean recorded blood pressure was lower when the larger cuff was used. ${ }^{9}$ In the 1946 cohort systolic pressure was also adjusted for cuff size. "In Preston systolic pressure was adjusted for age at examination. ${ }^{4}$ In Hertfordshire systolic pressure was adjusted for age at examination and ambient temperature and for sex where men and women were considered together.

Analysis was by tabulation of means using approximate fourths of the marginal variables and by multiple linear regression. In Farnborough and Hertfordshire, birth weight and weight at 1 year were used as joint regression variables to determine the relative contributions of prenatal and infant weight gain in the prediction of blood pressure.

\section{Results}

RELATION OF BLOOD PRESSURE TO BIRTH WEIGHT AND WEIGHT GAIN IN INFANCY

\section{Farnborough}

Mean (SD) birth weight was 3411 (459) $g$ for boys and $3282(431) \mathrm{g}$ for girls. Mean (SD) gestation was $39.7(1 \cdot 0)$ and $39.8(1 \cdot 1)$ weeks respectively. Only children with weights recorded at birth and 1 year were included in this part of the analysis. To enable comparison with other studies ${ }^{6}$ we analysed systolic pressure at age 4 years, when there were 521 boys and 470 girls.

Systolic pressure was higher in children who were heavier at age 4 years. Systolic pressure rose by 1.3 $(95 \%$ confidence interval 1.0 to 1.6$) \mathrm{mm} \mathrm{Hg}$ for every $\mathrm{kg}$ increase in current weight. Table II shows correlation coefficients between weight and body mass index at different ages. Children with higher birth weight and weight at 1 year tended to be heavier at 4 years. Table III shows the relation between systolic blood pressure and birth weight at different levels of current weight. Children who had lower birth weights tended to have higher systolic pressure at any level of current weight. This was found in both sexes and was little changed by adjusting birth weight for duration of gestation. Table IV shows a simultaneous analysis of the relation of birth weight and weight at 1 year with systolic pressure, taking account of weight at 4 years. Systolic pressure decreased by $2.8 \mathrm{~mm} \mathrm{Hg}$ for every $\mathrm{kg}$ increase in birth weight. There was no relation with weight at 1 year. 


\section{Hertfordshire}

Mean (SD) birth weight was 3587 (590) $\mathrm{g}$ for men and 3441 (536) $\mathrm{g}$ for women. Systolic pressure was higher in men and women who had a higher body mass index (weight/height $\left.{ }^{2}\right)$, rising by $1.0(0.6$ to 1.3$) \mathrm{mm} \mathrm{Hg}$ for every unit increase in body mass index. Table II shows that, as in children, men and women with higher birth weight and weight at 1 year tended to have higher body mass at 64 years, though the relation was small and the same for weight at 1 year as for birth weight. Table V shows the relation between systolic blood pressure and birth weight at different levels of current body mass. As in children, men and women who had lower birth weights tended to have higher systolic pressure at any level of current body mass. This was found in both sexes. Table VI shows the simultaneous relation of birth weight and weight at 1 year with systolic pressure, taking account of current body mass. Systolic pressure decreased by $4.0 \mathrm{~mm} \mathrm{Hg}$ for every $\mathrm{kg}$ increase in birth weight. There was no relation with weight at 1 year. The relation of diastolic pressure (adjusted for age and ambient temperature) to birth weight, weight at 1 year, and current body mass was similar to that of systolic pressure, though weaker.

RELATION OF SYSTOLIC PRESSURE AT DIFFERENT AGES TO BIRTH WEIGHT

Table I brings together the relation between birth weight and systolic blood pressure in all four studies. Systolic pressure was regressed simultaneously on birth weight and a measure of concurrent size, weight in children and body mass index in adults. Table I and figure 1 show the regression coefficients at each age. These give the mean difference in systolic pressure per $\mathrm{kg}$ increase in birth weight.

Mean systolic pressure rose with age. The inverse

TABLE V-Mean systolic pressure $(\mathrm{mm} \mathrm{Hg})$ at age 64 years according to birth weight and current body mass index

\begin{tabular}{llllll}
\hline & \multicolumn{5}{c}{ Body mass index at $64\left(\mathrm{~kg} / \mathrm{m}^{2}\right)$} \\
\cline { 2 - 5 } Birth weight (pounds) & To 24.1 (n=308) & To 26.4 (n=301) & To $29 \cdot 0(\mathrm{n}=313)$ & $>29 \cdot 0(\mathrm{n}=303)$ & Total $(\mathrm{n}=1225)$ \\
\hline To 7 & $156(\mathrm{n}=109)$ & $165(\mathrm{n}=88)$ & $168(\mathrm{n}=101)$ & $169(\mathrm{n}=82)$ & $164(\mathrm{n}=380)$ \\
To 7.75 & $162(\mathrm{n}=70)$ & $164(\mathrm{n}=71)$ & $167(\mathrm{n}=51)$ & $162(\mathrm{n}=58)$ & $164(\mathrm{n}=250)$ \\
To 8.5 & $159(\mathrm{n}=79)$ & $164(\mathrm{n}=66)$ & $164(\mathrm{n}=90)$ & $170(\mathrm{n}=78)$ & $164(\mathrm{n}=313)$ \\
$>8 \cdot 5$ & $152(\mathrm{n}=50)$ & $153(\mathrm{n}=76)$ & $163(\mathrm{n}=71)$ & $165(\mathrm{n}=85)$ & $159(\mathrm{n}=282)$ \\
Total & 158 & 162 & 166 & 167 & $163^{\star}$ \\
\hline
\end{tabular}

$\star$ Overall standard deviation $=24 \mathrm{~mm} \mathrm{Hg}$.

TABLE VI-Regression analysis of relation of birth weight and weight at 1 year to systolic blood pressure at age 64 years, taking account of sex and current body mass

\begin{tabular}{lccc}
\hline & $\begin{array}{c}\text { Mean difference in } \\
\text { systolic pressure } \\
\text { (mm Hg) per kg } \\
\text { increase in weight }\end{array}$ & $\begin{array}{c}95 \% \\
\text { Confidence } \\
\text { interval }\end{array}$ & p Value \\
\hline $\begin{array}{l}\text { Birth weight }(\mathrm{kg}) \\
\text { Weight at } 1 \text { year }(\mathrm{kg})\end{array}$ & -4.0 & -6.5 to -1.5 & $<0.005$ \\
$\begin{array}{l}\text { Body mass index }\left(\mathrm{kg} / \mathrm{m}^{2}\right) \\
\text { at } 64 \text { years }\end{array}$ & 0.03 & -1.2 to 0.3 & 0.96 \\
\hline
\end{tabular}

Standard error of residuals $=23.1 \mathrm{~mm} \mathrm{Hg}$.

TABLE VII-Mean systolic pressure ( $\mathrm{mm} \mathrm{Hg}$ ) at ages 59 to 71 years according to birth weight by age and sex

\begin{tabular}{lccccc}
\hline & \multicolumn{2}{c}{ Men } & & \multicolumn{2}{c}{ Women } \\
\cline { 2 - 3 } \cline { 5 - 6 } Birth weight (pounds) & $59-63$ Years $(n=426)$ & $64-70$ Years $(n=418)$ & $60-63$ Years $(n=203)$ & $64-71$ Years $(n=184)$ \\
\hline To 5.5 & $166(n=17)$ & $171(n=18)$ & & $156(n=10)$ & $169(n=9)$ \\
To 6.5 & $163(n=53)$ & $168(n=53)$ & & $156(n=35)$ & $165(n=33)$ \\
To 7.5 & $162(n=120)$ & $168(n=144)$ & & $162(n=73)$ & $160(n=68)$ \\
To 8.5 & $163(n=136)$ & $165(n=111)$ & & $163(n=48)$ & $163(n=48)$ \\
$>8.5$ & $161(n=100)$ & $163(n=92)$ & & $152(n=37)$ & $155(n=26)$ \\
Total & 162 & 166 & & 159 & 161 \\
Standard deviation & 23 & 24 & 23 & 26 \\
\hline
\end{tabular}

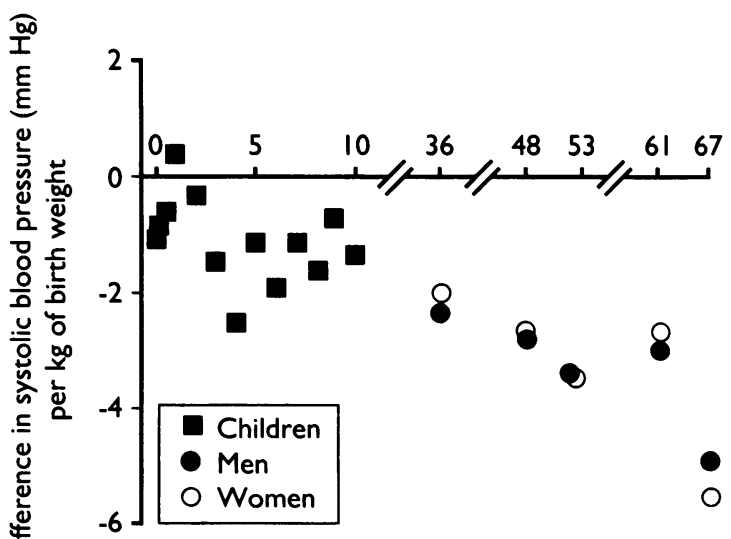

Relation between systolic pressure and birth weight at different ages

relation between birth weight and systolic pressure was apparent in pressure measurements made from the early months of life up to the age of 71 years. The strength of this relation, as indicated by the size of the regression coefficient, increased with age. To take account of the increase in standard deviation of systolic pressure with increasing age (table I) the regression coefficients at each age were divided by the standard deviation. These adjusted regression coefficients remained larger in adults than in children.

As an illustration of the stronger relation between birth weight and systolic pressure with age, the mean pressures, adjusted for ambient temperature, are shown for the men and women in Hertfordshire at ages 59-63 years and 64-71 years (table VII). In each sex the difference in systolic pressure between people who had low or high birth weights was greater at the older age. For men and women aged 64 to 71 years systolic pressure decreased by $5 \cdot 2(1.8$ to 8.6$) \mathrm{mm} \mathrm{Hg}$ for every $\mathrm{kg}$ increase in birth weight, after allowing for current body mass.

\section{Discussion}

At all ages beyond infancy people who had lower birth weight had higher systolic pressure (table I). Though small babies tend to become small children and small adults (table II) systolic pressure is also higher in people who are heavy in childhood and adult life. Thus the highest systolic pressures are found in people who had low birth weight but become heaviest (tables III and V). This group of people has also been shown to have a high prevalence of non-insulin dependent diabetes. ${ }^{12}$

The samples which we studied were different in age, place of birth, and residence. However, the relations of systolic pressure with birth weight and weight at 1 year were consistent. The loss to follow up in Farnborough is unlikely to have biased our findings as the birth weights and other measures of those who were followed up were similarly distributed to the original sample.' Similarly, in Preston and Hertfordshire the early weights were not different between those who did or did not participate in the study.

We showed that weight gain in infancy is not related to later blood pressure after birth weight and current weight or body mass are allowed for (tables IV and VI). This suggests that high blood pressure is initiated prenatally rather than during infancy. Consistent with previous findings among adults in Preston, ${ }^{4}$ and among children in Salisbury ${ }^{6}$ and in a national cohort, ${ }^{5}$ the Farnborough data show that the relation of systolic pressure with birth weight does not depend on shortened gestation. We therefore conclude that high blood pressure is initiated by processes associated with reduced growth in utero. The relation between blood pressure and reduced growth is not confined to babies 
with intrauterine growth retardation defined by birth weight at the lowest centiles. It is also seen in babies of around average weight.

We found that the relation between systolic pressure and birth weight becomes evident in the early months of life and grows stronger with increasing age (tables I and VII). We therefore suggest that the relation initiated in utero becomes amplifed in later life. This amplification could depend on a feedback mechanism which progressively increases an initially raised systolic pressure from infancy to old age. Such amplification could determine the progressive dispersion of blood pressure, indicated by the increase in standard deviation around the mean (table I) with increasing age.

We suggest that adult hypertension is determined by initiating and amplification mechanisms, as Folkow proposed, ${ }^{1}$ and that these are both set in place in utero, though compounded by later obesity. Two groups of babies develop high blood pressure in later life. One is thin at birth, as indicated by a low ponderal index; the other is short in relation to its head size and has above average placental weight. ${ }^{13}$ The relative contribution of initiating and amplifying effects to the development of hypertension may differ in the two groups, and we are currently studying this.

We can speculate on the processes which underlie initiation and amplification. The initiating process could be changes in fetal blood flow, perhaps resulting from perfusion of a large placenta, since large placental size in relation to fetal size is a strong predictor of blood pressure in adults. ${ }^{4}$ Alternatively, it might be increased activity of a trophin or mitogen, leading to changes in the vessel wall and subsequently a rise in blood pressure. Suggested trophins include growth hormone, insulin, insulin-like growth factor I (somatomedin C) sympathetic nerves, catecholamines, and angiotensin II. ${ }^{3}$ A wide variety of endocrine changes have been shown in growth retarded fetal sheep; these include lower blood concentrations of insulin and increased concentrations of adrenaline and noradrenaline. ${ }^{14}$

The feedback mechanism which amplifies the initiating effects with age could depend on progressive changes in the structure or compliance of blood vessels. In humans and in animals, vascular structure and compliance change with haemodynamic load. ${ }^{15}$ An increase in peripheral resistance and pulse pressure in early life could alter structure and reduce compliance, which in turn would increase pulse pressure. A feedback mechanism could thereby become established. ${ }^{16}$
Whatever the mechanisms, further understanding of the causes of essential hypertension may lie in knowledge of the processes which control fetal growth.

We are grateful to all the subjects who gave us their time, also to Mrs F Foden and the medical records staff of Sharoe Green Hospital, Preston, and Hertfordshire County Archives, who preserved the records and allowed us to use them; and the staff of the NHS central register, Southport, Lancashire, and Hertfordshire Family Health Service Authorities, and general practitioners in Lancashire and Hertfordshire who traced the subjects in Preston and Hertfordshire. The fieldwork in Preston was carried out by $M$ Ward and $M$ Kelly. The fieldwork in Hertfordshire was carried out by $P$ Harwood, $S$ Haynes, P Howell, R Rosenthal, and S Wolfe. We are grateful to the Medical Research Council and the British Heart Foundation for funding the Farnborough study, and the Dunhill Medical Trust, British Heart Foundation, and the Wessex Medical Trust for funding the Hertfordshire studies. We are grateful to Mr P Winter and Mr G Wield for assistance with computing.

1 Folkow B. Cardiovascular structural adaptation: its role in the initiation and maintenance of primary hypertension. Clin Sci 1978;55:3-22S.

2 Ferris J, Brown J, Fraser R, Haywood E, Davies D, Kay A, et al. Results of adrenal surgery in patients with hypertension, aldosterone excess and low plasma renin concentration. BMF 1975; i: 135-8.

3 Lever A, Harrap S. Essential hypertension: a disorder of growth with origins in childhood. F Hyperten 1992:10:101-20.

4 Barker D, Bull A, Osmond C, Simmonds S. Fetal and placental size and risk of hypertension in adult life. BMf 1990;301:259-62.

5 Barker D, Osmond C, Golding J, Kuh D, Wadsworth M. Growth in utero, blood pressure in childhood and adult life, and mortality from cardiovascular disease. $B M F$ 1989;298:564-7.

6 Law C, Barker D, Bull A, Osmond C. Maternal and fetal influences on blood pressure. Arch Dis Child 1991;66:1291-5.

7 Cruise M. A longitudinal study of the growth of low birthweight infants. Pediatrics 1973;51:322-7.

8 Scott A, Moar V, Ounsted M. Growth in the first four years. I. The relative effects of gender and weight for gestational age at birth. Early Hum Dev 1982;7:17-28.

9 De Swiet M, Fayers P, Shinebourne E. Blood pressure in first 10 years of life: the Brompton study. $B M \mathcal{F}$ 1992;304:23-6.

10 Ounsted M, Cockburn J, Moar V, Redman C. Factors associated with the blood pressures of children born to women who were hypertensive during pregnancy. Arh Dis Child 1985;60:631-5.

11 Wadsworth M, Cripps H, Midwinter R, Colley J. Blood pressure in a national birth cohort at the age of 36 years, related to social and familial factors, birth cohort at the age of 36 years, related to

12 Hales C, Barker D, Clarke P, Cox L, Fall C, Osmond C, et al. Fetal and infan growth and impaired glucose tolerance at age 64. BMF 1991;303:1019-22.

13 Barker D, Godfrey K, Osmond C, Bull A. The relation of fetal length, ponderal index and head circumference to blood pressure and the risk of hypertension in adult life. Paed Perinatal Epidemiol 1992;6:35-44.

14 Owens J, Owens P, Robinson J. Experimental fetal growth retardation metabolic and endocrine aspects. In: Gluckman PD, Johnston BM, Nathanielsz PW, eds. Advances in fetal physiology. Ithaca, New York: Perinatalogy Press, 1989:263-86.

5 Berry C. Hypertension and arterial development: long-term considerations. Br Heart f 1978;40:709-17.

16 Folkow B. Physiological aspects of primary hypertension. Physiol Rev 1982;62:347-504.

(Accepted 30 October 1992)

\section{ONE HUNDRED YEARS AGO}

\section{LONDON AS A PLACE OF OCCASIONAL STUDY.}

Every year the desire to be up to date drives a larger and larger number of medical men to spend part at least of their holidays in study, and a constant stream of Colonial, American, and other English-speaking wanderers passes through the Continental medical schools, picking up such crumbs of knowledge as their degree of familiarity with foreign languages will permit. Perhaps if the enormous advantages of London as a place of occasional study were as well known as they should be, many would stay here instead of going further. The prospectus of the London Post-Graduate Course shows how thoroughly a couple of months can be filled up; but it by no means covers the whole field which is open to the enterprising stranger. If any special line is to be studied, a small sum spent in fees will put the student not merely on the benches of a lecture room, but in actual touch with the daily practice of most of the special hospitals. For those who wish to see the surgical procedures of the leading operators the theatres of all the hospitals are practically open for occasional visitors, although at none of the hospitals to which schools are attached can the stranger easily come in contact with the patient or do more than take his place among the crowd of students. Going round the wards of a school hospital is not always satisfactory, at any rate to the amour propre of the distinguished stranger; but by doing ward and out-patient work at the special hospitals, attending such portion of the Post-Graduate Course as may be of most interest, and taking full advantage of such operative and clinical work at the school hospitals as is done in the theatres, an immense amount of information may be picked up regarding the actualities of medical and surgical practice.

(BMF 1893;i:1237.) 